\title{
CORRECTIONS
}

\section{Publisher Correction: Rarefied nutrition}

\section{Grant Otto}

Correction to: Nature Reviews Microbiology https://doi.org/10.1038/s41579-021-00516-9, published online 20 January 2021.

In the original version of the article, the first author of the highlighted article was incorrect and has now been corrected to Bay et al. in the pdf and online. We apologize to the authors and readers for any confusion caused.

https://doi.org/10.1038/s41579-021-00522-x I Published online 25 January 2021

(C) Springer Nature Limited 2021

\section{Publisher Correction: Structural insights into RNA polymerases of negative-sense RNA viruses}

\author{
Aartjan J. W. te Velthuis (D), Jonathan M. Grimes (iD) and Ervin Fodor(D)
}

Nature Reviews Microbiology (2021) https://doi.org/10.1038/s41579-020-00501-8 Published online 25 January 2021.

In the original version of this article, the names of reviewers in the peer review information section were incorrect. It should have stated that Nature Reviews Microbiology thanks R. Fearns, M. Rosenthal and the other, anonymous, reviewer(s) for their contribution to the peer review of this work. The error has now been corrected online. We apologize to the readers for any confusion caused.

https://doi.org/10.1038/s41579-021-00524-9 I Published online 2 February 2021

(c) Springer Nature Limited 2021 